\title{
Differential responses between mature and young leaves of sunflower plants to oxidative stress caused by water deficit
}

\author{
Diferentes respostas entre folhas adultas e jovens de plantas de girassol ao estresse oxidativo causado \\ pelo déficit hídrico
}

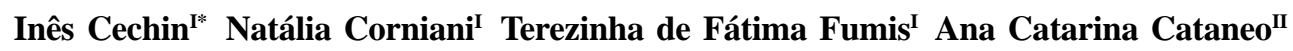

\begin{abstract}
The effects of water stress and rehydration on leaf gas exchange characteristics along with changes in lipid peroxidation and pirogalol peroxidase (PG-POD) were studied in mature and in young leaves of sunflower (Helianthus annuus L.), which were grown in a greenhouse. Water stress reduced photosynthesis $\left(P_{n}\right)$, stomatal conductance $\left(g_{s}\right)$, and transpiration $(E)$ in both young and mature leaves. However, the amplitude of the reduction was dependent on leaf age. The intercellular $\mathrm{CO}_{2}$ concentration $\left(C_{i}\right)$ was increased in mature leaves but it was not altered in young leaves. Instantaneous water use efficiency (WUE) in mature stressed leaves was reduced when compared to control leaves while in young stressed leaves it was maintained to the same level as the control. After $24 \mathrm{~h}$ of rehydration, most of the parameters related to gas exchange recovered to the same level as the unstressed plants except $g_{s}$ and $E$ in mature leaves. Water stress did not activated $P G-P O D$ independently of leaf age. However, after rehydration the enzyme activity was increased in mature leaves and remained to the same as the control in young leaves. Malondialdehyde (MDA) content was increased by water stress in both mature and young leaves. The results suggest that young leaves are more susceptible to water stress in terms of gas exchange characteristics than mature leaves although both went through oxidative estresse.
\end{abstract}

Key words: photosynthesis, antioxidant enzymes, lipid peroxidation, rehydration, Helianthus annuus.

\section{RESUMO}

Os efeitos do estresse hídrico e da reidratação nas trocas gasosas juntamente com alterações na lipoperoxidação $e$ atividade da pirogalol peroxidase (PG-POD) foram estudados em folhas adultas e jovens de plantas de girassol (Helianthus annuus L.) cultivadas em casa de vegetação. O estresse hídrico reduziu a fotossíntese $\left(P_{N}\right)$, a condutância estomática $\left(g_{s}\right)$ e a transpiração (E) nas folhas adultas e jovens. No entanto, a amplitude da redução foi dependente da idade da folha. A concentração intercelular de $\mathrm{CO}_{2}\left(C_{i}\right)$ aumentou nas folhas adultas, mas não apresentou alteração nas folhas jovens sob condições de estresse hídrico. A eficiência instantânea do uso da água (WUE) nas folhas adultas e estressadas foi reduzida em comparação com o controle, enquanto que, nas folhas jovens e estressadas, não foi alterada. Após $24 h$ de reidratação, as folhas apresentaram valores semelhantes aos dos controles em todos os parâmetros relacionados com as trocas gasosas, exceto $g_{s}$ e E nas folhas adultas. $O$ estresse hídrico não ativou a PG-POD, independente da idade da folha, e após a reidratação a atividade da $P G-P O D$ foi aumentada apenas nas folhas adultas. $O$ estresse hídrico aumentou o teor de malondialdeído (MDA) nas folhas adultas e jovens. Os resultados sugerem que as folhas jovens são mais susceptívies ao déficit hídrico em termos de trocas gasosas que as folhas adultas, embora ambas tenham sido expostas ao estresse oxidativo.

Palavras-chave: fotossíntese, enzimas antioxidantes, lipoperoxidação, reidratação, Helianthus annuus.

\section{INTRODUCTION}

Drought stress is a problem in arid and semiarid areas and also in those where the demand for transpiration is very high. Under this stressful

\footnotetext{
I'Departamento de Ciências Biológicas, Faculdade de Ciências, Universidade Estadual Paulista (UNESP), 17033-360, Bauru-SP, Brasil. E-mail: icechin@fc.unesp.br. *Autor para correspondência.

"I Departamento de Química e Bioquímica, Instituto de Biociências, UNESP, 18618-000, Botucatu-SP, Brazil.
} 
condition, the rate of $\mathrm{CO}_{2}$ fixation is negatively affected, mainly due to stomata closure (CHAVES et al., 2003). With the closure of the stomata, the plants reduce not only water loss by transpiration, but also $\mathrm{CO}_{2}$ supply to the leaves (BAKER, 1993), and, as a result, plant growth is reduced. The reduction in $\mathrm{CO}_{2}$ fixation implies in excess of energy citation intercepted by the photosynthetic pigments. This may result in the formation of excessive levels of reactive oxygen species (ROS), which are potentially harmful to all cellular components (SMIRNOFF, 1993). The ROS can have impacts on cells via oxidation of proteins, lipids and DNA (GARG \& MANCHANDA, 2009). Under normal conditions, the plants have the capacity to cope with the production of ROS which are products of aerobic metabolism by eliminating them via efficient enzymatic and non-enzymatic antioxidant systems (NOCTOR \& FOYER, 1998).

Plants have several antioxidant enzymes located in different cell compartments. Peroxidases are ubiquitous group of oxido-reductases present in most plant tissues which catalyze the breakdown of $\mathrm{H}_{2} \mathrm{O}_{2}$. Peroxidases are often the first enzymes to alter their activity under stress (GARG \& MANCHANDA, 2009). Under stressful conditions the development of oxidative stress is a result of the imbalance between the formation of ROS and their detoxification capacity (MITTLER, 2002). Plants respond to stress in part by modulating their genetic expression, which results in restoration of cellular homeostasis, detoxification of toxins and recovery of growth (XIONG \& ZHU, 2002).

In most studies, the effect of drought has been analysed on mature leaves and the few available data comparing the effect of water stress on mature and young leaves indicate that the photosynthetic responses to water stress are strongly dependent on leaf age (DAVID et al., 1998). It has been demonstrated that leaves formed under water-limiting conditions appeared more drought tolerant than those formed under well watered conditions and subsequently exposed to stress (MONTI et al., 2007).

The aim of this study was to detect differences between the physiological responses of mature and young leaves of sunflower plants to water deficit. Additionally, the ability of plants to recover from water deficit was evaluated.

\section{MATERIAL AND METHODS}

The experiment was conducted in a greenhouse situated in the city of Bauru, São Paulo, Brazil (22'21'28'S, 4901'37'W) in November-December 2004, under natural photoperiod with maximum day and night temperatures close to 32 e $18^{\circ} \mathrm{C}$, respectively.
Seeds of sunflower (Helianthus annuus L. var. CATISSOL-01) were sown in $8 \mathrm{dm}^{3}$ pots filled with a 47:13:40\% pinus bark, vermiculite and peat mixture and seedlings were thinned to one per pot after emergence. The space between the pots and the lines was sufficient to avoid shading between the plants. The plants were supplied with $300 \mathrm{~cm}^{3}$ of a $50 \%$ full strength Long Ashton solution (HEWITT, 1966) per pot, twice a week, and with tap water on the other days. The substrate moisture in the pots was maintained close to field capacity until 26 days after sowing. Irrigation was then partially suspended in a separate set of pots until the observation of photosynthesis inhibition. This corresponded to a period of six days. The water stress was terminated by rehydration the pots again. In order to obtain a slowly rate of stress, the pots of stressed plants were covered with plastic to avoid evaporation from the substrate and received $150 \mathrm{~cm}^{3}$ of $50 \%$ Long Ashton solution (HEWITT, 1966) twice a week and the same amount of tap water on the other days. Control (irrigated) plants were maintained to field capacity throughout the experiment and also received the same amount of Long Ashton (HEWITT, 1966) solution as the stressed plants.

Leaf gas exchange, leaf water potential, malondialdehyde (MDA) content and activity of pirogalol peroxidase (PG-POD; EC 1.11.1.7) were determined at the vegetative stage 34 days after sowing on mature fully expanded leaves ( 8 and 9 , numbered acropetally) and young expanding leaves which had a length between $4-5 \mathrm{~cm}$ at the time of stress imposition and had continued their growth under water-limiting conditions. The leaves used in the analysis were situated in the middle stratum of the plants. A portable infra-red gas analyzer (LCpro, ADC, Hoddesdon, UK) was used for measurements of photosynthesis $\left(P_{N}\right)$, stomatal conductance to water vapor $\left(g_{s}\right)$, transpiration $(E)$ and intercellular $\mathrm{CO}_{2}$ concentration $\left(C_{i}\right)$. Measurements were taken between 8 and 10 am.inside the greenhouse and photosynthetic active radiation (PAR) of $1800 \mu \mathrm{mol} \mathrm{m}^{-2} \mathrm{~s}^{-1}$ was supplied by a light unit mounted on the top of leaf chamber. However, due to the leaf chamber window transmission factor the PAR incident on leaf surface was $1602 \mu \mathrm{mol} \mathrm{m} \mathrm{m}^{-2} \mathrm{~s}^{-1}$. Water vapor and $\mathrm{CO}_{2}$ concentration differences between inlet and outlet gas circulating through the leaf chamber, as well as leaf temperatures obtained from energy balance equation were used to calculate $P_{N}, E$ and $g_{s}$ on a leaf area basis by using the equations described by von CAEMMERER \& FARQUHAR (1981). $P_{N}, E$ and $g_{s}$ were use to calculate the intercellular $\mathrm{CO}_{2}$ concentration. Instantaneous water use efficiency (WUE) was computed as the ratio between $P_{N}$ and $E$. 
Leaf water potential ( $\Psi$ ) was determined by using a Scholander pressure bomb (model 3005, Soilmoisture Equipment Corp., Santa Barbara, USA). The extraction and activity of PG-POD were determined according to EKLER et al. (1993) and TEISSEIRE \& GUY (2000), respectively. Protein was determined according to LOWRY et al. (1951) and serum albumin was used as standard. The activity of PG-POD was expressed as $\mu$ mol purpurogalin $\mathrm{min}^{-1} \mathrm{mg}^{-1}$ protein. The content of MDA was determined according to the method described by HEATH and PACKER (1968). The MDA content was calculated by its extinction coefficient of $155 \mathrm{mmol} \mathrm{L}^{-1} \mathrm{~cm}^{-1}$ and expressed as nmol $\mathrm{g}^{-1}$ fresh matter.

The plants were distributed over a completely randomized layout, with three treatments and ten replicates, totaling 30 pots. Statistical analysis were carried out by one-way ANOVA using Tukey test, taking $\mathrm{P}<0.05$ as significant.

\section{RESULTS AND DISCUSSION}

The leaf water potential ( $\psi_{\text {leaf }}$ ) decreased as the water deficit increased in both mature and young leaves of sunflower plants (Table 1). Although the young stressed leaves had lower $\psi_{\text {leaf }}$ than the control leaves, their $\psi_{\text {leaf }}$ was also lower than that of the mature stressed leaves. The accumulation of osmolyte compounds such as proline in the cells as a result of water stress is often associated with a possible mechanism to tolerate the harmful effect of water shortage (CLIFFORD et al., 1998). In sunflower, the young stressed leaves synthesized nearly seven times more proline than non-stressed leaves while the mature stressed leaves synthetized it only four times more
(CECHIN et al., 2006). This may explain the lower $\psi_{\text {leaf }}$ young stressed leaves found in this study. Both young and mature leaves were able to recovery $\psi_{\text {leaf }}$ to the same level as the control leaves within $24 \mathrm{~h}$ of rehydration. After 6 days of water deficit, $E$ decreased by about 40 and $63 \%$ in mature and young leaves, respectively (Table 1). When the water-stressed plants were rewatered for $24 \mathrm{~h}, E$ of young leaves recovered to the same control level but mature leaves did not recovered. The leaf water status and carbon uptake is under stomata control and stomata closure is one of the earliest responses to drought, thus protecting the plants against harmful dehydration but also inevitably reduces the $\mathrm{CO}_{2}$ uptake for photosynthesis which reduces diffusion of $\mathrm{CO}_{2}$ into the leaf $\left(C_{i}\right.$ decreases $)$. Drought depressed $g_{\mathrm{s}}$ by about 57 and $77 \%$ in mature and young leaves, respectively, but leaf $g_{\mathrm{s}}$ fully recovered after $24 \mathrm{~h}$ rehydration only in young leaves (Table 1). The fact that mature stressed leaves were not able to recovered their $E$ and $g_{s}$ after $24 \mathrm{~h}$ of rehydration may be associated to low $\psi_{\text {leaf }}$ value ($0,51 \mathrm{MPa})$ compared to controle $(-0,27 \mathrm{MPa})$.

The $C_{i}$ value of mature stressed leaves was higher than that of control leaves while that of young leaves was similar to the control values. After $24 \mathrm{~h}$ of rehydration, mature leaves recovered the $C_{i}$ value to the same level as the control. Instantaneous WUE in mature stressed leaves was reduced compared to control leaves while in young stressed leaves it was maintained to the same level as the control due to the same percentage of reduction in $P_{\mathrm{N}}$ and in $E$ caused by water stress. Leaf age had a significant effect on $P_{N}$, with young leaf having higher $P_{N}$ than mature leaf. The reduction in $P_{\mathrm{N}}$ under water stress was more marked in young than mature leaves. In contrast, MONTI et al.

Table 1 - Leaf water potential ( $\left.\Psi_{\text {leaf }}, \mathrm{MPa}\right)$, photosynthesis $\left(P_{N}, \mu \mathrm{mol} \mathrm{m}^{-2} \mathrm{~s}^{-1}\right)$, stomatal conductance $\left(g_{\mathrm{s}}, \mathrm{mol} \mathrm{m}^{-2} \mathrm{~s}^{-1}\right)$, transpiration $(E$, mmol $\left.\mathrm{m}^{-2} \mathrm{~s}^{-1}\right)$, intercellular $\mathrm{CO}_{2}$ concentration $\left(C_{i}, \mu \mathrm{mol} \mathrm{mol}^{-1}\right.$ ), instantaneous water use efficiency (WUE, $P_{N} / E$ ), MDA content $\left(\mathrm{nmol} \mathrm{g}{ }^{-1}\right.$ fresh matter) and PG-POD activity $\left(\mu \mathrm{mol} \mathrm{min} \mathrm{m}^{-1} \mathrm{mg}^{-1}\right.$ protein) in sunflower plants under 6 days of drought and after $24 \mathrm{~h}$ of rehydration.

\begin{tabular}{|c|c|c|c|c|c|c|}
\hline & Control & Stressed & Rehydrated & Control & Stressed & Rehydrated \\
\hline$\Psi_{\text {leaf }}$ & $-0,27 \pm 0,01 a^{1}$ & $-1,08 \pm 0,13 b$ & $-0,51 \pm 0,07 \mathrm{a}$ & $-0,35 \pm 0,03 a$ & $-1,29 \pm 0,12 b$ & $-0,39 \pm 0,05 a$ \\
\hline$P_{N}$ & $18,86 \pm 1,28 \mathrm{a}$ & $8,58 \pm 0,61 b$ & $15,80 \pm 0,91 \mathrm{a}$ & $21,87 \pm 0,84 a$ & $7,52 \pm 1,97 \mathrm{~b}$ & $21,99 \pm 0,83 a$ \\
\hline$g_{s}$ & $0,37 \pm 0,04 \mathrm{a}$ & $0,16 \pm 0,01 b$ & $0,25 \pm 0,03 b$ & $0,43 \pm 0,01 \mathrm{a}$ & $0,10 \pm 0,03 b$ & $0,36 \pm 0,01 \mathrm{a}$ \\
\hline$E$ & $4,40 \pm 0,23 \mathrm{a}$ & $2,67 \pm 0,15 b$ & $3,47 \pm 0,24 \mathrm{c}$ & $4,76 \pm 0,11 \mathrm{a}$ & $1,76 \pm 0,46 b$ & $4,16 \pm 0,07 \mathrm{a}$ \\
\hline$C_{i}$ & $216,40 \pm 4,61 \mathrm{a}$ & $253,00 \pm 5,49 b$ & $210,40 \pm 10,01 \mathrm{a}$ & $210,80 \pm 4,64 a$ & $208,00 \pm 10,79 a$ & $193,00 \pm 8,32 \mathrm{a}$ \\
\hline WUE & $4,28 \pm 0,14 \mathrm{a}$ & $3,21 \pm 0,16 b$ & $4,6 \pm 0,25 \mathrm{a}$ & $4,59 \pm 0,13 \mathrm{ab}$ & $4,20 \pm 0,30 \mathrm{a}$ & $5,29 \pm 0,21 b$ \\
\hline MDA & $0,61 \pm 0,06 \mathrm{a}$ & $1,27 \pm 0,23 b$ & $1,27 \pm 0,12 b$ & $0,91 \pm 0,08 \mathrm{a}$ & $1,66 \pm 0,14 b$ & $1,85 \pm 0,07 \mathrm{~b}$ \\
\hline PG-POD & $0,79 \pm 0,08 \mathrm{a}$ & $0,76 \pm 0,06 \mathrm{a}$ & $1,23 \pm 0,15 b$ & $1,03 \pm 0,14 \mathrm{a}$ & $1,18 \pm 0,13 a$ & $1,22 \pm 0,09 a$ \\
\hline
\end{tabular}

${ }^{1}$ Values are means \pm SE of 4-5 plants. Values sharing the same letters are not significantly different at $\mathrm{P}<0.05$ according to Tukey test. 
(2007) demonstrated that the reduction of photosynthetic efficiency of sugar beet leaves was generally moderate in young leaves and drastic as leaf aged.

Stomatal closure without a change in mesophyll capacity will inevitable lower $C_{i}$. The results suggest that in sunflower plants, stomatal closure is not fully responsible for the reduction in $P_{N}$ because $C_{\mathrm{i}}$ remained nearly the same as the control in young stressed leaves, in spite of decreased $g_{s}$. Moreover, in mature stressed leaves $C_{i}$ increased possibly due to metabolic causes. The stomata control is important only under mild stress (CORNIC, 2000). However, inhibition of photosynthesis also takes place at mild water stress (TEZARA et al., 1999) and it becomes more important as the water stress intensifies. FLEXAS \& MEDRANO (2002) explained that the metabolism gets impaired as a consequence of decreased synthesis of ribulose bisphosphate and ATP in the early phases of water stress and only under severe stress, decreased ribulose-1,5-bisphosphate carboxylase/oxygenase activity and photochemistry are reported. In addition, changes observed in photochemical activity of PS2 can partly contribute to the metabolic limitations of $P_{N}$ in sunflower under water deficit (TEZARA et al., 2008). It has been shown that the ability of photosynthetic activity to recover after relief of water stress is dependent on leaf age (DAVID et al., 1998). However, this is not the case in the present study where both mature and young leaves fully recovered the rates of photosynthesis after rehydration, indicating that damage to the photosynthetic apparatus did not occur under this level of water stress. The activity of PG-POD was not altered in both mature and young leaves under water stress (Table 1). This does not imply that sunflower plants go through no oxidative stress since it was observed high levels of MDA in both mature and young leaves compared to control plants. This suggests that PG-POD may have limited contribution to water stress in sunflower plants. On the other hand, increase in MDA level might also be correlated with inadequate activities of other ROS scavenging enzyme such as superoxide dismutases (SOD) and catalase (CAT).

The ROS can be produced by different reactions in plants and some of them are activated during abiotic stress (MITTLER, 2002). Some studies have reported that water stress produces oxidative stress as a consequence of increased ROS and also that many plants are able to cope with this by activating the ROS scavenging enzymes (SIMOVA-STOILOVA et al., 2009). Under drought stress, when $\mathrm{CO}_{2}$ assimilation is reduced, there is a production of mainly superoxide and singlet oxygen in the chloroplasts (SMIRNOFF, 1993). Superoxide dismutases is a family of enzymes located in chloroplasts, cytosol, mitochondria, peroxisomes, and apoplast that catalyze the dismutation of $\mathrm{O}_{2}^{-}$into $\mathrm{H}_{2} \mathrm{O}_{2}$. Peroxidases with broad specificity are located in vacuoles, cell walls, and the cytosol and use $\mathrm{H}_{2} \mathrm{O}_{2}$ in substrate oxidation.

The ROS are generated during dessication and, especially during the first phase of rehydration in Boea hygroscopica, when $\mathrm{H}_{2} \mathrm{O}_{2}$ and oxidative stress increase (SGHERRI et al., 1994). Also, accumulations of $\mathrm{O}_{2}^{-}$and $\mathrm{H}_{2} \mathrm{O}_{2}$ still occurred in Kentucky bluegrass when relative water content was fully recovered (BIAN $\&$ JIANG, 2009) and high levels of MDA were found after recovery of water stress in seedlings of Lotus corniculatus, a low drought-tolerant species (OLSSON et al., 1996). This suggests that under rapid rehydration some injury may occur. After $24 \mathrm{~h}$ of rehydration, the activity of PG-POD in mature leaves was increased compared to control leaves but there was no indication of PG-POD activation in young leaves (Table 1). This activation is important in preserving the integrity of membrane under damage caused by rapid rehydration (KAISER, 1987). However, 24h of rehydration were not sufficient to reduce the level of lipid peroxidation in both mature and young leaves or to change the activation of PG-POD in mature leaves (Table 1). It is interesting to note that the rate of $\mathrm{CO}_{2}$ fixation was recovered to the same level as the control in both mature and young leaves after $24 \mathrm{~h}$ of rehydration in spite of high levels of lipid peroxidation. This suggests that this level of peroxidation is not large enough to affect $\mathrm{CO}_{2}$ assimilation in sunflower plants.

It has been shown that the activity of the antioxidant enzymes such as SOD, ascobate peroxidase (APO) and CAT are higher in young than in old leaves of sunflower while peroxidase showed lower activity in young than in old leaves (SAIRAM et al., 2003). This may explain the lack of activation of PG-POD in young leaves observed in this study.

Taken all together, the current research shows that water stress had more negative effect on gas exchange characteristics of young leaves but both mature and young leaves were able to fully recover after $24 \mathrm{~h}$ of rehydration. Oxidative stress, indicated by the level of MDA, was observed in both mature and young leaves. With respect to antioxidative responses, neither water stress nor rehydration was able to induce PG-POD activity in young leaves. Future studies are needed in order to compare the antioxidative capacity between mature and young leaves under water stress.

\section{ACKNOWLEDGEMENTS}

I.C. and N.C thank the Brazilian agencies FAPESP and FUNDUNESP for financial support.

\section{REFERENCES}

BAKER, N.R. Light-use efficiency and photoinhibition of photosynthesis in plants under environmental stress. In: SMITH, 
J.A.C.; GRIFFITHS, H. Water deficits plant responses from cell community. Oxford: Bios Scientific Publisher, 1993. p. 221-235.

BIAN, S.; JIANG, Y. Reactive oxygen species, antioxidant enzyme activities and gene expression patterns in leaves and roots of Kentucky bluegrass in response to drought stress and recovery. Scientia Horticulturae, v.120, p. 264-270, 2009.

CECHIN, I. et al. Photosynthetic responses and proline content of mature and young leaves of sunflower plants under water deficit. Photosynthetica. v.44, p. 43-146, 2006. Available from: $<\mathrm{http}: / /$ www.springerlink.com/content/7v814gw43q51231x/>. Accessed on: 29 jan. 2010. doi: 10.1007/s11099-005-0171-2.

CHAVES, M.M. et al. Understanding plant response to drought: from genes to the whole plant. Functional Plant Biology, v.30, p.239-264, 2003.

CLIFFORD, S.C. et al. The role of solute accumulation, osmotic adjustment and changes in cell wall elasticity in drought tolerance in Ziziphus mauritana (Lamk.). Journal of Experimental Botany, v.49, p.967-977, 1998.

CORNIC, G. Drought stress inhibits photosynthesis by decreasing stomatal aperture - not by affecting ATP synthesis. Trends in Plant Science, v.5, p.187-188, 2000. Available from: <http:/ $/ \mathrm{w}$ w w. s c i e n c e d i r e c t l c c c m / science?_ob=ArticleURL\&_udi=B6TD1-405SNF9$3 \&$ us e r $=972052 \&$ coverDate $=05 \% 2$ F $01 \% 2$ $\mathrm{F} 2000$ \&_rdoc $=1 \&$ fmt $=\overline{\mathrm{h}}$ igh\&_orig $=\mathrm{search} \&$ sort $=\mathrm{d} \&$ docanchor $=\&$ view $=c \&$ c acct $=C 000049647 \& \_v e r s i o n=1 \&$ urlVersion $=0 \& \_u s e r i d=972052 \& \mathrm{md} 5=0$ e695ef905b9757aef43436f6>. Accessed on: 29 jan. 2010. doi.org/10.1016/S13601385(00)01625-3.

DAVID, M.M. et al. Leaf age effects on photosynthetic activity and sugar accumulation in droughted and rewatered Lupinus albus plants. Australian Journal of Plant Physiology, v.25. p.99-306, 1998.

EKLER, Z. et al. Safener effects on acetochlor toxicity, uptake, metabolism and glutathioneS-transferase activity in maize. Weed Research, v.33, p.311-318, 1993.

FLEXAS, J.; MEDRANO, H. Drought-inhibition of photosynthesis in $\mathrm{C}_{3}$ plants: stomatal and non-stomatal limitations revisited. Annals of Botany, v.89, p.183-189, 2002. Available from: <http://aob.oxfordjournals.org/cgi/ reprint/89/2/183>. Accessed on: 29 jan. 2010.

GARG, N.; MANCHANDA, G. ROS generation in plants: Boon or bane? Plant Biosystems, v.143, p.1-96, 2009.

HEATH, R.L.; PACKER, L. Photoperoxidation in isolated chloroplasts I. Kinetic and stoichiometry of fatty acid peroxidation. Archives of Biochemistry and Biophysics, v.125, p.189-198, 1968.

HEWITT, E.J. Sand and water culture methods used in the study of plant nutrition. Farnham Royal, England: Commonwealth Agricultural Bureaux, 1966. 547p.

KAISER, W.M. Effects of water defficitt on photosynthetic capacity. Physiologia Plantarum, v.71, p.142-149, 1987.

LOWRY, O.H. et al. Protein measurement with Folin-phenol reagent. Journal Biological Chemistry, v.193, p.265-275, 1951.
MITTLER, R. Oxidative stress, antioxidants and stress tolerance. Trends in Plant Science, v.7, p.405-410, 2002. Available from: <http:// www.sciencedirect.com/science?_ob=ArticleURL\&_udi=B6TD146HNR7P-1\&_user $=972052 \&$ _coverDate $=09 \% 2 \mathrm{~F} 01 \% 2 \mathrm{~F} 2002 \&$ _rdoc $=1 \&$ f fmt $=$ high \&_orig =search\&_sort $=\mathrm{d} \&$ _ 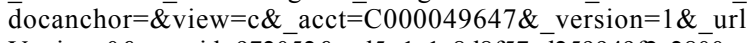 Version $=0 \&$ userid $=972052 \& \mathrm{md} 5=1 \mathrm{a} 1 \mathrm{a} 8 \mathrm{~d} 8 \mathrm{f} 57 \mathrm{~cd} 259949 \mathrm{f} 2 \mathrm{e} 2800>$. Accessed on: 29 jan. 2010. doi.org/10.1016/S1360-1385(02)02312-9.

MONTI, A. et al. Photosynthesis on individual leaves of sugar beet (Beta vulgaris) during the ontogeny at variable water regimes. Annals of Applied Biology, v.151, p.155-165, 2007.

NOCTOR, G.; FOYER, C. Ascorbate and glutathione: keeping active oxygen under control. Annual Review Plant Physiology Molecular Biology, v.49, p.249-279, 1998. Available ifrom: <http://arjournals.annualreviews.org/doi/abs/ 10.1146\%2Fannurev.arplant.49.1.249>. Accessed on: 29 jan. 2010. doi: $10.1111 /$ j. 1744-7348.2007.00162.x.

OLSSON, M. et al. Drought stress in seedlings: lipid metabolism and lipid peroxidationduring recovery from drought in Lotus corniculatus and Cerastium fontanum. Physiologia Plantarum, v.96, p.577-584, 1996.

SAIRAM, R. K. et al. Changes in activities of antioxidant enzymes in sunflower leas of different ages. Biologia Plantarum, v.47, p.61-66, 2003. Available from: <http:// www.springerlink.com/content/k37q64r897626862/>. Accessed on: 29 jan.. 2010. doi:10.1023/A:1027328814591.

SGHERRI, C. L. et al. Antioxidant system in Boea hygroscopica: changes in response to desiccation and rehydration. Phytochemistry, v.37, p.77-381, 1994.

SIMOVA-STOILOVA, L. et al. Antioxidative protection and proteolytic activity in tolerant and sensitive wheat (Triticum aestivum L.) varieties subjected to long-term field drought. Plant Growth Regulator, v.58, p.107-117, 2009. Available from: $<$ http://www.springerlink.com/content/j662874087711116/>. Accessed on: 29 jan. 2010. doi:10.1007/s10725-008-9356-6.

SMIRNOFF, N. Transley Review No. 52. The role of active oxygen in the response of plants to water deficit and dessication. New Phytologist, v.125, p.27-58, 1993.

TEISSEIRE, H.; GUY, V. Copper-induced changes in antioxidant enzymes activities in frond of duckweed (Lemna minor). Plant Science, v.153, p.65-72, 2000.

TEZARA, W. et al. Partitioning of photosynthetic electron flow between $\mathrm{CO}_{2}$ assimilation and $\mathrm{O}_{2}$ reduction in sunflower plants under water deficit. Photosynthetica, v.46, p.127134, 2008. Available from: http://www.springerlink.com/ content/qrku1171110u15qp/. Accessed on: 29 jan. 2010. doi: 10.1007/s11099-008-0020-1.

TEZARA, W. et al. Water stress inhibits plant photosynthesis by decreasing coupling factor and ATP. Nature, v.401, p.914$917,1999$.

von CAEMMERER, S.; FARQUHAR, G.D. Some relationships between the biochemistry of photosynthesis and the gas exchange of leaves. Planta, v.153, p.376-387, 1981.

XIONG, L.; ZHU, J.-K. Molecular and genetic aspects of plant responses to osmotic stress. Plant Cell Environment, v.25, p.131139, 2002. Available from: <http://www3.interscience.wiley.com/ journal/118948773/abstract>. Accessed on: 29 jan. 2010. doi: 10.1046/j.1365-3040.2002.00782.x. 